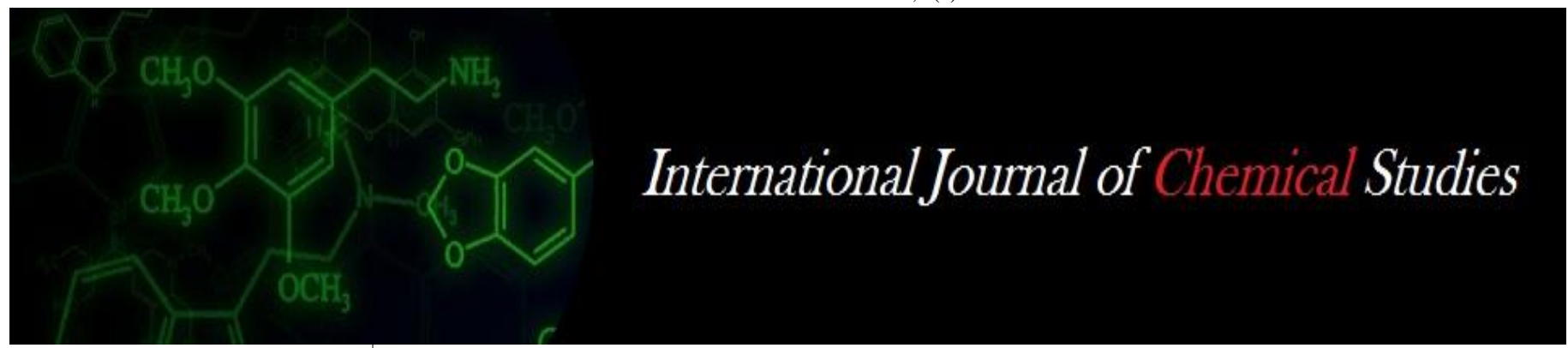

P-ISSN: 2349-8528

E-ISSN: 2321-4902

www.chemijournal.com

IJCS 2021; 9(1): 2210-2213

(C) 2021 IJCS

Received: 24-10-2020

Accepted: 05-12-2020

Lakshmidevamma TN

College of Horticulture, Bidar,

Karnataka, India

Jagadeesha RC

College of Horticulture, Bidar,

Karnataka, India

Hanchinamani CN

College of Horticulture, Bidar,

Karnataka, India

Arunkumar KT

College of Horticulture, Bidar,

Karnataka, India
Corresponding Author: Lakshmidevamma TN

College of Horticulture, Bidar,

Karnataka, India

\section{Genetic variability, heritability and genetic advances in chilli (Capsicum annuum)}

\author{
Lakshmidevamma TN, Jagadeesha RC, Hanchinamani CN and \\ Arunkumar KT
}

DOI: https://doi.org/10.22271/chemi.2021.v9.i1ae.11546

\begin{abstract}
The present investigation was carried out to find out the variability, heritability and genetic advance in chilli (Capsicum annuum L.) at the College of Horticulture, Bidar. The experiment was laid out in randomized block design. All the treatments were randomly distributed among the plots and were replicated two times. Transplanting of seedlings was done at spacing of $60 \times 45 \mathrm{~cm}$. The observations were recorded on five plants per plots for days to 50 per cent flowering, days to maturity plant height, number of branches per plant, number of fruits per plant, fruit length, fruit width, test weight and yield per plant. The genotypes GCA-1 has recorded significantly higher yield per plant of $638 \mathrm{~g}$, while lower yield per plant was recorded in GPM-41 of $79 \mathrm{~g}$. Number of branches per plant (13) was noticed in Pant C-1 and maximum number of fruit per plant was noticed in genotype Nalchatii (37.50).
\end{abstract}

Keywords: Chilli, genetic advance, genetic variability, growth, and yield

\section{Introduction}

Chilli is one of the most important vegetable crops grown throughout India. It belongs to family Solanaceae with chromosome number $2 n=24$. It is grown for export as well as for domestic market. Chilli contributes about $33 \%$ of the total spice export from India and share about $16 \%$ of the world spice trade (Kadwey et al., 2016) ${ }^{[4]}$. In India, chilli is grown in area of $9,40,000$ ha as it is specially liked for its pungency, aroma and spicy taste. India is the second largest producer of vegetables after China and also maximum numbers of vegetable crops are grown due to great diversity of agro climatic condition. A wide range of variability reportedly exists in this crop, (Nandi, 2012) ${ }^{[9]}$. The genetic information gathered on yield and yield attributing traits would be of utility in formulation of an efficient breeding programme for the improvement of chilli crop in order to develop promising genotypes/ hybrids. Yield is a determining factor for crop improvement (Addissu, 2012) ${ }^{[2]}$. Its yield is a quantitative trait that is influenced by a number of yield contributing parameters. The selection of desirable genotypes is usually based on yield and yield components. It is therefore necessary to study the mutual relationship between yield and yield components for efficient utilization of the genetic stock in crop improvement program of chili pepper. Variability in plants is the first step in understanding how to improve or produce new plants. Heritability is the degree of genetic control associated to some important traits (Nechif et al., 2011) ${ }^{[10]}$. The present study was under taken to estimate the variability, and correlation section includes for identification of promising genotypes to use in genetic improvement of chilli. The present investigation was conducted to determine the direction variability and degree of association among the characters.

\section{Material and Methods}

The studies were carried out at College of Horticulture, Bidar. The basic material for the study involved 45 diverse chilli genotypes laid in two replications in randomized block design. Five plants were selected randomly from each genotype and replication. All the cultural operation was carried out as per package of practices of UHS, Bagalkot. The observations were recorded on five competitive plants taken at random over the replications on fruit length, fruit girth, fruit width, plant height, number of branches per plant, Number of fruits per plant, yield per plant and days to maturity. The details of genotypes given in table number 1 . 


\section{Results and Discussion}

The estimate of genetic parameters viz., phenotypic and genotypic coefficient of variation along with heritability in broad sense and genetic advance as percentage of mean for different characters are given in (Table 2). A wide variation in the mean performance of parents was observed for all the characters under study. The extent of variability with respect to various characters in different genotypes measured in terms of range, general mean, genotypic coefficient if variation, phenotypic coefficient of variation along with heritability and expected genetic advance as percent of mean (Table 2.). yield per plant showed maximum range of variability from 79.00 to 638.00 with a mean of 287.99 followed by day to maturity from 135.00 to 166.50 along with a grand mean of 148.93 , days to 50 per cent flowering from 92.50 to 115.00 along with a grand mean of 102.56, plant height from 20.04 to $71.00 \mathrm{~cm}$ along with a grand mean $34.82 \mathrm{~cm}$, fruit length from 2.88 to $8.99 \mathrm{~cm}$ along with a grand mean of $6.28 \mathrm{~cm}$, fruit weight from 4.63 to $24.07 \mathrm{~mm}$ along with a grand mean of $9.23 \mathrm{~mm}$ and Murda incidence from 1.00 to 3.50 along with a grand mean of 2.15. The magnitude of phenotypic coefficient of variability was higher than that of genotypic coefficient of variability for all the characters except yield per plant and murda incidence indicating that effect of environment on their genetic expression. Maximum phenotypic coefficient of variation (per cent) was obtained for yield per plant (61.54) followed by Number of fruit per plant of 58.88, fruit width (36.04), plant height of 29.99, Murda incidence of 29.62 number of branches per plant (29.46), fruit length (23.71), test weight of 14.79 and days to $50 \%$ flowering (7.16). The maximum amount of genotypic coefficient of variation (per cent) was observed for yield per plant (63.09) followed by Number of fruit per plant of 55.56, fruit width (35.40), plant height of 28.51, Murda incidence of 38.24, number of branches per plant (23.70), fruit length (22.38), test weight of 13.95 and days to $50 \%$ flowering (6.89). These results indicated that higher magnitude of genotypic coefficient of variation for the above traits offer a better opportunity for improvement through selection. Similar findings were reported by (Acharya et al., 2007; Maurya et al.,2015) [5], (Pujar et al., 2017; Nahak et al., 2018) ${ }^{[8]}$. The genotypic coefficient of variation provides help to measure the genetic variability in a character and accordingly, it is not possible to partition existing heritable variation in population based solely on this estimate. According to this the maximum heritability was observed for fruit weight of 96.00 per cent whereas the lowest heritability was observed for murda incidence of 60.00 per cent. These findings are in accordance with the observations made by (Tembhurne, et al., 2008) ${ }^{[13]}$, (Mishra, et al., 2002) [7] and (Negi and Sharma, 2019) [11]. High heritability in broad sense indicated that large proportion of phenotypic variance was attributable to the genotypic variance and were less influenced by environment. Hence, selection can bring worthwhile improvement in these traits. Genetic advance is still a more useful estimate because heritability value by itself does have much significance as it fails to account for the magnitude of absolute variability. It is therefore, necessary to utilize heritability in conjunction with selection differential which would then indicate the expected genetic gain resulting from selection. The yield per plant has maximum value (123.65), succeeded by number of fruit per plant (108.00),fruit width (71.61), plant height (55.82), murda incidence (47.26), fruit length (43.50), Number of branches (39.28) , days to 50 per cent flowering (13.66) and days to maturity (12.79). The results of present investigation are also in agreement with the findings reported by (Ukkund et al, 2007) ${ }^{[14]}$, (Gupta, et al., 2009) ${ }^{[3]}$, (Addissu et al, 2012) ${ }^{[3]}$ and (Meena et al, 2016) ${ }^{[6]}$. High estimates of heritability along with high genetic advance provide good scope for further improvement in advance generation if characters subject mass progeny or family selection.

Table 1: Details of genotypes

\begin{tabular}{|c|c|c|c|c|c|}
\hline Sl. No. & Genotypes & Sl. No. & Genotypes & Sl. No. & Genotypes \\
\hline 1 & GPM-31 & 16 & GPM-55 & 31 & Pragna \\
\hline 2 & GPM-33 & 17 & GPM-56 & 32 & Reshem Patto \\
\hline 3 & GPM-34 & 18 & GPM-57 & 33 & Achari \\
\hline 4 & GPM-36 & 19 & GPM-58 & 34 & Nalchatti \\
\hline 5 & GPM-37 & 20 & GPM-59 & 35 & Bamra \\
\hline 6 & GPM-38 & 21 & GPM-60 & 36 & Pant C-1 \\
\hline 7 & GPM-39 & 22 & KCA-2 & 37 & KCA-17-1 \\
\hline 8 & GPM-40 & 23 & KCA-21-1 & 38 & KA-2 \\
\hline 9 & GPM-41 & 24 & Parekh & 39 & BD Sel-1 \\
\hline 10 & GPM-42 & 25 & HP-2 & 40 & Pusa Jwala \\
\hline 11 & GPM-43 & 26 & KCA-24-1 & 41 & BK Sel-1 \\
\hline 12 & GPM-45 & 27 & KCA-20-1 & 42 & G-4 \\
\hline 13 & GPM-51 & 28 & KDL Deluxe & 43 & BK Sel-2 \\
\hline 14 & GPM-52 & 29 & KCA-19-1 & 44 & GCA-1 \\
\hline 15 & GPM-54 & 30 & KCA-18-1 & 45 & GCA-2 \\
\hline
\end{tabular}

Table 2: Range, mean, genotypic, phenotypic coefficient of variability, heritability and genetic advance for different characters in chilli

\begin{tabular}{|c|c|c|c|c|c|c|c|}
\hline \multirow{2}{*}{ Parameters } & \multirow{2}{*}{ Mean } & \multicolumn{2}{|c|}{ Range } & \multirow{2}{*}{ PCV $(\boldsymbol{\%})$} & \multirow{2}{*}{ GCV $(\boldsymbol{\%})$} & \multirow{2}{*}{ Heritability (\%) } & \multirow{2}{*}{ Genetic advance \% of mean } \\
\cline { 3 - 8 } & & Minimum & Maximum & & & & \\
\hline Days to 50\% flowering & 102.567 & 92.50 & 115.00 & 7.16 & 6.89 & 0.93 & 13.66 \\
\hline Day to Maturity & 148.933 & 135.00 & 166.50 & 6.64 & 6.42 & 0.94 & 12.79 \\
\hline Plant height & 34.826 & 20.04 & 71.00 & 29.99 & 28.51 & 0.90 & 55.82 \\
\hline Number of branches & 7.942 & 4.50 & 13.00 & 29.46 & 23.70 & 0.65 & 39.28 \\
\hline Number of fruits & 12.567 & 4.50 & 37.50 & 58.88 & 55.56 & 0.89 & 108.00 \\
\hline Fruit length & 6.284 & 2.88 & 8.99 & 23.71 & 22.38 & 0.89 & 43.50 \\
\hline Fruit width & 9.235 & 4.63 & 24.07 & 36.04 & 35.40 & 0.96 & 71.61 \\
\hline Test weight & 4.494 & 2.98 & 6.15 & 14.79 & 13.95 & 0.89 & 27.11 \\
\hline Yield per plant & 287.99 & 79.00 & 638.00 & 61.54 & 63.09 & 0.95 & 123.65 \\
\hline Murda incidence & 2.156 & 1.00 & 3.50 & 29.62 & 38.24 & 0.60 & 47.26 \\
\hline
\end{tabular}


Table number3. Character means of different chilli genotypes

\begin{tabular}{|c|c|c|c|c|c|c|c|c|c|c|c|}
\hline \begin{tabular}{|l|} 
Sl. \\
No.
\end{tabular} & $\begin{array}{c}\text { Name of the } \\
\text { accession }\end{array}$ & \begin{tabular}{|c|} 
Days to 50\% \\
flowering \\
\end{tabular} & $\begin{array}{c}\text { Day to } \\
\text { Maturity }\end{array}$ & $\begin{array}{c}\text { Plant } \\
\text { height }\end{array}$ & \begin{tabular}{|c|}
$\begin{array}{c}\text { Number of } \\
\text { branches per plant }\end{array}$ \\
\end{tabular} & \begin{tabular}{|c|}
$\begin{array}{c}\text { Number of } \\
\text { fruits per plant }\end{array}$ \\
\end{tabular} & $\begin{array}{c}\text { Fruit } \\
\text { length }\end{array}$ & $\begin{array}{l}\text { Fruit } \\
\text { width }\end{array}$ & $\begin{array}{c}\text { Test } \\
\text { weight }\end{array}$ & $\begin{array}{c}\text { Incidence of } \\
\text { leaf curl }\end{array}$ & \begin{tabular}{|c|}
$\begin{array}{c}\text { Yield per } \\
\text { plant }\end{array}$ \\
\end{tabular} \\
\hline 1 & GPM-31 & 115.00 & 162.50 & 33.00 & 10.50 & \begin{tabular}{|l|}
9.00 \\
\end{tabular} & 6.95 & 9.93 & 3.87 & 2.00 & 194.00 \\
\hline 2 & GPM-33 & 104.00 & 149.00 & 27.20 & 5.50 & 13.50 & 6.15 & 14.91 & 4.56 & 2.50 & 525.00 \\
\hline 3 & GPM-34 & 92.50 & 137.50 & 26.84 & 7.50 & 7.00 & 6.01 & 9.49 & 4.50 & 2.00 & 270.00 \\
\hline 4 & GPM-36 & 96.50 & 141.00 & 37.50 & 6.00 & 5.50 & 5.69 & 8.94 & 4.47 & 2.00 & 134.00 \\
\hline 5 & GPM-37 & 108.00 & 152.50 & 20.04 & 5.50 & 8.00 & 8.05 & 6.87 & 3.92 & 3.00 & 115.00 \\
\hline 6 & GPM-38 & 95.50 & 135.00 & 33.00 & 10.50 & 9.00 & 6.82 & 8.84 & 5.34 & 2.00 & 151.00 \\
\hline 7 & GPM-39 & 95.00 & 137.50 & 36.40 & 7.00 & 17.50 & 8.18 & 8.90 & 4.36 & 2.50 & 320.00 \\
\hline 8 & GPM-40 & 95.00 & 135.00 & 27.83 & 9.00 & 16.00 & 4.85 & 12.20 & 4.20 & 1.50 & 309.00 \\
\hline 9 & GPM-41 & 112.50 & 162.50 & 29.00 & 11.00 & 4.50 & 6.82 & 10.05 & 4.60 & 3.00 & 79.00 \\
\hline 10 & GPM-42 & 107.50 & 158.00 & 25.63 & 9.50 & 31.00 & 7.17 & 6.37 & 4.02 & 1.00 & 548.00 \\
\hline 11 & GPM-43 & 95.00 & 135.00 & 36.50 & 9.50 & 10.50 & 7.74 & 6.72 & 4.28 & 2.50 & 185.00 \\
\hline 12 & GPM- 45 & 106.50 & 155.00 & 30.13 & 5.88 & 7.00 & 5.37 & 7.11 & 6.15 & 2.50 & 140.00 \\
\hline 13 & GPM-51 & 96.50 & 144.50 & 47.00 & 8.20 & 11.00 & 4.20 & 8.83 & 4.77 & 2.50 & 246.50 \\
\hline 14 & GPM-52 & 92.50 & 140.00 & 33.50 & 9.50 & 8.50 & 6.65 & 6.59 & 3.60 & 2.00 & 115.00 \\
\hline 15 & GPM-54 & 95.00 & 142.50 & 20.50 & 7.00 & 10.00 & 4.17 & 9.67 & 4.66 & 2.50 & 160.00 \\
\hline 16 & GPM-55 & 101.00 & 155.00 & 39.45 & 9.75 & 17.50 & 7.20 & 7.56 & 4.01 & 2.50 & 440.00 \\
\hline 17 & GPM-56 & 102.50 & 152.50 & 59.50 & 7.20 & 11.00 & 7.99 & 10.61 & 5.11 & 2.50 & 285.00 \\
\hline 18 & GPM-57 & 110.00 & 157.50 & 27.83 & 5.90 & 7.00 & 6.03 & 9.26 & 4.51 & 3.50 & 144.50 \\
\hline 19 & GPM-58 & 95.50 & 142.50 & 24.73 & 6.40 & 9.00 & 5.54 & 9.38 & 5.76 & 2.50 & 335.50 \\
\hline 20 & GPM-59 & 106.50 & 152.50 & 40.90 & 8.20 & 9.00 & 6.99 & 7.12 & 4.99 & 1.00 & 280.50 \\
\hline 21 & GPM-60 & 106.50 & 152.50 & 30.50 & 6.60 & 6.50 & 4.55 & 8.82 & 4.84 & 3.50 & 85.00 \\
\hline 22 & KCA-2 & 95.50 & 137.50 & 41.45 & 6.60 & 12.50 & 8.63 & 8.98 & 3.88 & 2.00 & 462.50 \\
\hline 23 & KCA-21-1 & 92.50 & 135.00 & 44.50 & 4.50 & 11.00 & 4.85 & 7.46 & 4.23 & 2.50 & 351.00 \\
\hline 24 & Parekh & 109.00 & 159.00 & 32.50 & 9.50 & 7.00 & 4.41 & 5.66 & 5.05 & 3.00 & 142.00 \\
\hline 25 & HP-2 & 96.50 & 140.00 & 26.38 & 4.88 & 7.00 & 8.22 & 12.79 & 4.29 & 2.00 & 273.00 \\
\hline 26 & KCA-24-1 & 115.00 & 162.50 & 53.38 & 5.63 & 12.50 & 5.30 & 9.40 & 4.82 & 1.50 & 511.00 \\
\hline 27 & KCA-20-1 & 102.50 & 147.50 & 42.28 & 7.10 & 14.00 & 6.97 & 10.52 & 4.45 & 1.50 & 604.00 \\
\hline 28 & KDL Deluxe & 114.00 & 166.50 & 31.54 & 8.50 & 4.50 & 8.90 & 9.40 & 4.52 & 3.00 & 159.00 \\
\hline 29 & KCA-19-1 & 113.50 & 165.00 & 36.00 & 9.34 & 6.50 & 6.04 & 5.66 & 3.87 & 3.00 & 121.00 \\
\hline 30 & KCA-18-1 & 109.00 & 162.50 & 28.00 & 8.38 & 22.50 & 6.75 & 6.70 & 3.91 & 1.00 & 475.00 \\
\hline 31 & Pragna & 110.00 & 160.00 & 34.90 & 11.00 & 28.50 & 6.40 & 8.95 & 5.68 & 1.00 & 575.00 \\
\hline 32 & Reshem Patto & 105.00 & 151.00 & 43.50 & 7.38 & 9.00 & 6.27 & 24.07 & 5.55 & 1.50 & 559.50 \\
\hline 33 & Achari & 101.00 & 152.00 & 27.25 & 5.25 & 13.00 & 5.60 & 17.26 & 3.69 & 1.50 & 165.00 \\
\hline 34 & Nalchatti & 110.00 & 155.00 & 71.00 & 11.50 & 37.50 & 5.40 & 8.02 & 2.98 & 1.00 & 547.00 \\
\hline 35 & Bamra & 95.00 & 137.50 & 27.50 & 9.34 & 10.00 & 2.88 & 4.63 & 4.49 & 2.00 & 80.00 \\
\hline 36 & Pant C-1 & 96.00 & 142.50 & 30.00 & 13.00 & 17.50 & 3.90 & 9.38 & 3.33 & 2.50 & 225.50 \\
\hline 37 & KCA-17-1 & 105.00 & 150.00 & 42.63 & 10.50 & 22.50 & 4.92 & 8.51 & 3.50 & 1.00 & 371.00 \\
\hline 38 & KA-2 & 113.50 & 162.50 & 22.25 & 5.00 & 7.00 & 6.83 & 9.11 & 4.94 & 3.50 & 93.00 \\
\hline 39 & BD Sel-1 & 101.00 & 150.00 & 27.75 & 5.50 & 6.50 & 4.92 & 13.81 & 4.55 & 2.50 & 140.00 \\
\hline 40 & Pusa Jwala & 102.50 & 147.50 & 39.95 & 7.20 & 11.00 & 6.33 & 6.67 & 4.81 & 2.50 & 270.00 \\
\hline 41 & BK Sel-1 & 109.00 & 155.00 & 23.60 & 6.30 & 7.00 & 8.04 & 7.90 & 4.62 & 2.50 & 117.00 \\
\hline 42 & G-4 & 106.50 & 151.00 & 28.20 & 6.10 & 13.50 & 6.05 & 6.64 & 5.02 & 1.50 & 202.00 \\
\hline 43 & BK Sel-2 & 96.50 & 137.50 & 38.20 & 11.40 & 22.00 & 8.14 & 9.33 & 4.79 & 1.00 & 499.00 \\
\hline 44 & GCA-1 & 95.50 & 140.00 & 43.93 & 7.90 & 18.50 & 8.99 & 8.29 & 4.70 & 1.00 & 638.00 \\
\hline \multirow[t]{5}{*}{45} & GCA-2 & 92.50 & 135.00 & 43.53 & 9.50 & 16.50 & 4.98 & 8.38 & 4.12 & 2.50 & 317.00 \\
\hline & Mean & 102.57 & 148.93 & 34.83 & 7.94 & 12.57 & 6.28 & 9.24 & 4.49 & 2.16 & 287.99 \\
\hline & $\mathrm{CV}(\%)$ & 1.95 & 1.69 & 9.31 & 17.50 & 19.49 & 7.85 & 6.79 & 4.92 & 24.18 & 13.92 \\
\hline & C.D. 5\% & 4.03 & 5.06 & 6.53 & 2.80 & 4.94 & 0.99 & 1.26 & 0.45 & 1.05 & 40.60 \\
\hline & S.E. & 1.41 & 1.78 & 2.29 & 0.98 & 1.73 & 0.35 & 0.44 & 0.16 & 0.37 & 14.24 \\
\hline
\end{tabular}

\section{References}

1. Acharya P, Sengupta S, Mukherjee S. Genetic variability in pepper (Capsicum annuum). Environment and Ecology 2007;25(4):808-812.

2. Addissu AG. Heritability and genetic advance in recombinant inbred lines for drought tolerance and other related traits in sorghum (Sorghum bicolor) Continental Journal Agricultural Science 2012;5:1-9.

3. Gupta AM, Daljeet Singh, Kumar Ajay. Genetic variability, genetic advance and correlation in chilli (Capsicum annuum L.). Indian Journal of Agricultural Sciences 2009;793:221-223

4. Kadwey S, Dadiga A, Prajapati S. Genotypes performance and genetic variability studies in hot chilli
(Capsicum anпиum L.).Indian Journal of Horticultural Sciences 2016;50(1):56-60.

5. Maurya AK, Kushwaha ML, Singh BK. Genetic Studies in Chilli (Capsicum annuum L.). The International Journal Of Science \& Technology 2015;3(8):289-290.

6. Meena ML, Kumar N, Meena JK, Rai T. Genetic variability, heritability and genetic advances in chilli, Capsicum annuum. Biosci. Biotech. Res. Comm 2016;9(2):258-262.

7. Mishra AC, Singh RV, Ram HH. Path coeffi cient analysis in sweet pepper (Capsicum annuum L.) genotypes under mid hills of Uttaranchal. Vegetable Science 2002;29(1):71-74. 
8. Nahak SC, Nandi A, Sahu GS, Tripathy P, Dash SK, Patnaik A, et al. Studies on variability, heritability and genetic advance for yield and yield contributing characters in chilli (Capsicum annuum L.). J. Pharmacogn. Phytochem 2018;7:2506-2510.

9. Nandi A. Genetic variability in chilli (Capsicum annuum L.). Indian Journal of Coca Arecanut and Spices 1992;16(3-4):140-05.

10. Nechif O, Filimon R, Szilagyi L. Genetic variability, heritability and expected genetic advance as indices for yield and yield components selection in common bean (Phaseolus vulgaris L.), Scientifi c Papers, UASVM Bucharest, Series 2011, 1222-5339.

11. Paramjeet Singh Negi, Akhilesh Sharma. Studies on Variability, Correlation and Path Analysis in Red Ripe Chilli Genotypes. Int. J. Curr. Microbiol. App. Sci 2019;8(4):1604-1612.

12. Pujar UU, Shantappa T, Jagadeesha RC, Gasti VD, Sandhyarani N. Genetic variability, heritablity, correlation and path analysis in chilli (Capsicum annuum L.). Int. J. Pure App. Biosci 2017;5:579-586.

13. Tembhurne BV, Revanappa R, Kuchanyr PH. Varietal performance, genetic variability and correlation studies in chilli (Capsicum annuum L.). Karnataka journal of Agricultural Sciences 2008;21(4):541-543.

14. Ukkund KC, Madalageri MB, Patil MP, Mulage R, Kotikal YK. Variability studies in green chilli (Capsicum annиum L.). Karnataka Journal of Agricultural Sciences 2007;20(1):102-104. 